\title{
Rapid Assessment of Tourism Impacts through Community Participation-A Pilot Study in Cuba for Projecting New Strategies of Management
}

\author{
Manuel Ramón González Herrera ${ }^{1}$, Mabel Font Aranda ${ }^{2}$ \\ ${ }^{1}$ Department of Tourism, Autonomous University of Ciudad Juarez, Ciudad Juárez, México \\ ${ }^{2}$ Department of Tourism, University of Matanzas, Matanzas, Cuba \\ Email: manglez04@yahoo.es
}

Received June $3^{\text {rd }}$, 2013; revised July $15^{\text {th }}$, 2013; accepted July 22 $2^{\text {nd }}, 2013$

\begin{abstract}
Copyright (c) 2013 Manuel Ramón González Herrera, Mabel Font Aranda. This is an open access article distributed under the Creative Commons Attribution License, which permits unrestricted use, distribution, and reproduction in any medium, provided the original work is properly cited.
\end{abstract}

\begin{abstract}
The report of the Rapid Assessment of tourism impacts through community participation is presented, based on a pilot study in Cuba to project new strategies of management. The purpose of this study is to develop a methodology to identify how tourism affects social organization in communities, in order to consider different policy implications and management options, at the same time, to conduct comparative studies to monitor vulnerabilities and the effectiveness of social and health-promoting policies. This project brings together researchers and community representatives from Cárdenas and Caibarién, two coastal communities in Cuba, to examine how the expansion of tourism in these communities directly and/or indirectly affects them. In relation to the general objective a conceptual framework is elaborated to explain pathways that link the impacts of tourism and the policies that influence them across their lifespan. A consensus is developed on indicators and research/measurement protocols based on a comprehensive review of existing evidence on these issues. A preliminary agreement is also promoted according to the policy implications and policy options of insights that can be gained regarding the impacts of tourism on local communities among policy-makers, researchers and community leaders.
\end{abstract}

Keywords: Tourism; Impacts; Community; Participation; Cuba

\section{Introduction}

To investigate the impact of tourism on local communities, it was decided that examination of how a specific global phenomenon can affect a specific community would provide useful insights (González, 2010) and help to assess the support of community residents for sustainable tourism development (Tsung, 2013; Kila, 2013). In this context, selection of a pilot study of how a Cuban community could be affected by the impacts of tourism development was identified as the focal point for the Globalization and Social Organization research program's first pilot study.

Travel and tourism in particular, as a form of entertainment or leisure has a long history leading up to the $20^{\text {th }}$ century when tourism developed into a multibillion dollar industry (Legrand, 2012) that spans virtually all countries, at the local, national and international levels (Edgell, 2013). Faster and more affordable air travel has contributed to more people reaching more remote places and with them their luggage of impacts on the local communities (Cooper, 2007).

The more recent world expansion of tourism has been largely attributed to the phenomenon of globalization (Spiegel \& Andruske, 2005). As the capitalist-free marketideology promotes privatization and deregulation with subsequent increased movement of capital, goods and people, some immediate outcomes are commodification of services and expansion of markets that encompass all areas including tourism.

The purpose of this pilot project is to develop a methodology for identifying how global forces affect social organization and health in communities; so that policy implications and options can be considered and comparative studies conducted to monitor vulnerabilities and the effectiveness of social and healthpromoting policies. Bringing together researchers and community representatives from Cárdenas and Caibarién, this project examines how the expansion of tourism in coastal communities-directly and indirectly-affects local communities.

In relation to it, the general research objectives are to:

- Develop a conceptual framework to explain pathways that link the impact of tourism (and the policies that influence this) to direct and indirect effects on the local communities across the lifespan (through impacts on social organization).

- Develop consensus on indicators and research/measurement protocols based on a comprehensive review of existing evidence on these issues, results from previous studies in which our team has been involved, and especially the original field research conducted in Cuba.

- Develop preliminary consensus on the policy implications and policy options of insights that can be gained regarding the impacts of globalization on local communities among policy-makers, researchers and community leaders.

Why Coastal Communities? In many ways, coastal commu- 
nities are especially vulnerable to the pressures of tourism development, and can serve as sentinels. The spatial, natural resource and ecological characteristics that have shaped their development historically (e.g. fishing, forestry) make them differentially subject to global changes (e.g. the primary resources exploitation previously favored can be threatened by ecological changes and global competition; while their "aesthetic settings" become global commodities as transportation technologies have evolved to support increases in people flows).

Why Tourism? Tourism, which has grown significantly since the late $80 \mathrm{~s}$, is today considered by many to be the world's biggest business. It brings together people from different parts of the globe on a massive scale and has significant impacts on political, cultural, social, economic and environmental conditions of the communities in which it is developed-all factors, which in turn have an impact on health.

While tourism can boost hard currency receipts, heavy infrastructure investment eats up resources that could be used elsewhere and often replaces one "single-crop" economy for another. Moreover, the benefits of tourism are not always evenly distributed. Tourism may lead to increased social, class and gender differentiation. Employment created in the community may be predominantly in low status, low paid and temporary jobs. Tourism can stimulate prostitution, sexually transmitted disease, drugs, alcohol and other community-disruptive behaviors and values. Furthermore, tourism development may lead to reduced access for local people to the natural resources on which they depend for their livelihoods and drive up the costs of land, food, manufactured goods and housing.

Why Gender and Health? An extensive literature shows that structural economic change affects women's and men's roles differently, with policies associated with "economic globalization" having a more negative impact on women and girls relative to men and boys, with women experiencing higher risks of poverty, domestic violence, and sexually transmitted diseases; and less access to health-related services overall. Applying a gender-based analysis (GBA) to examine the differential, yet interconnected, impacts of tourism expansion on men and women in coastal communities thus provides a highly appropriate prism for assessing the impacts of globalization.

\section{Literature Review}

In order to achieve a consequent socio-economic development, with the protection of the environment and in harmony with the life quality of local communities (Lankford, 2013), it is necessary to project strategic actions directed to minimize the adverse incidences of the current models and development styles in the environmental quality states of our planet (Mason, 2008; Guevara et al., 2009; González, 2010; Gössling, 2012). In this sense, effects generated by new human activities have become a permanent demand of society, because of their incidences in the natural, social and economic environment (Hall et al., 2003; Busch et al., 2005). In this respect, the paradigm of sustainable development constitutes a component of great importance whose analysis derives in indispensable condition to optimize the relationships between the receiving environment and different types of sociocultural and productive activities (Arcarons, 2005; Kila et al., 2013).

The analysis of this conception related to development reaches special connotation in the case of tourism, for the multiple and complex interactions that it generates with receiver envi- ronmental systems (Fernández, 2002; Edgell, 2013). Particular significance acquires this relationship in the geographical context of the tropical island systems, where a wide investor program takes place, with tendencies to increase (González, 2010). So; sustainable tourism development represents a challenge and the only alternative for new investment projects, as requirement to manage the Environmental, Sociocultural and Economic Impacts (Ayala, 2001; Organización Mundial de Turismo, 2005; Hall C., 2009).

Without doubts, the integrated administration of impacts of tourism is a viable focus for the strategic positioning of different geographical spaces as Sustainable Tourism Areas (Osácar \& Vilaginés, 2005). Tourism, like a factor of development demands of regional and local strategies that promote the implementation of Responsible Tourism Systems based on handling of impacts; with the purpose of minimize those of adverse character and to maximize the beneficent ones (CITMA, 2005; González, 2012; Harris, 2011). Under such focuses, it is opportune to guide the evaluation of current and future developments in function of quality of tourist destinations, based on the principles of sustainable development.

In this respect, it is necessary to follow promoting instruments of integrated management of impacts with the purpose to pass from the stage of correction solutions to preventive ones (González, 2010). This focus is incorporated to the multi-criteria decision making process like a requirement for the formulation of compatible environmental projects (Francesc Valls, 2004). That shows us that in the last decades new focuses have appeared for interpretation of relationships between human beings and their environment.

Frameworks trying to establish links between globalization and local communities have been developed in the last 20 years and, although there is a concurrence about their complexity and consequently the evaluation of the linkages, there is also concurrence about the fact that such links do exist and need to be addressed in order to mitigate the negative impacts (Labonte \& Torgerson, 2002; Spiegel et al., 2004; Huynen et al., 2005; Leigh, 2012; Ivars et al., 2013;).

The impact of tourism on communities has also been widely recognized and more direct links have been established in particular at the local level (Cohen, 1984; Taylor, 1993; Freitag, 1996; Stonich, 2000; Josep \& Kavoori, 2001; González, 2006; Kila et al., 2013). Similarly, the impact on other aspects is widely documented and acknowledged as in the hidden market of "sex tourism" (Wonders \& Michalowski, 2001), while the human resources for the industry are channelled along clear gender lines and community impacts can be similarly differentiated.

Cuba has not been exempt from the rising impacts of globalization (INIE, 2005). In fact, Cuba has been a significant, if somewhat belated player in the growth of the tourism sector with almost two million tourists visiting the country in 2005 mostly from Canada, Spain and other European countries. The collapse of the main trade partner, the Soviet Union, in 1989 forced Cuba to redesign its economic development by embracing tourism as the principal source of hard currency with $40 \%$ of the national revenues in recent years.

The almost overnight transition from sugar cane producer to service provider has presented Cuba with a few challenges not only in the economic arena, but in the political arena as well. Suddenly Cuba became exposed to "foreign" influences associated with the greater "global integration" of an expanded tour- 
ism sector that produced new challenges to forms of distinct social organization that had produced significant achievements in health, education and culture "on the margins" of an increasingly integrated processes of globalization (Spiegel et al., 2006).

Accepting the inevitability of tourism and its influence, $\mathrm{Cu}-$ ba's strategy has been to respond with its own innovative and social approach: 1) a tourism that is sustainable, and 2) policies that mitigate the negative impacts of tourism. Ultimately these two prongs are complementary and self-supporting. For instance, one aspect of sustainable tourism has been the community participation, through notable community members, in recognizing and managing solutions to health, cultural and environmental problems (Cabrera, 2004; González, 2006).

Significantly, Cuba has refused to accept one of the premises of globalization that is the diminished role of the State. On the contrary, government policies have played a major role in offsetting the negative outcomes of tourism on health specifically and other areas such as loss of local identity and values, economic migration of people, cultural clashes, economic inequality, job level friction, shifts in nutrition, crime generation, and prostitution and sex tourism.

Reflecting on Cuba's approach, our research has undertaken a pilot study that has developed methods for a more systematic analysis of impacts. There is no doubt that tourism is a health determinant. A conceptual framework that links the impact of tourism development on health has been built. This work has been reported elsewhere (Jerry et al., 2006). What seems to be elusive is a process that is able to systematically and rapidly gauge the nature and the extent of the impacts.

\section{Methodology}

This paper describes a methodology (Figure 1), that is able to gather and process information related to key questions addressed in the pilot study:

- Can the links between tourism development and impacts be systematically identified by the community?

- Are the tourism impacts different at different stages of tourism development?

- Can comprehensive qualitative and quantitative indicators be identified that might tell the tale of the "real" impact?

- Can both men and women be adequately represented by the indicators?

- Can mitigating policy measures for protecting and promoting development be identified?

- Can the findings be applied to a wider global community? Two communities in Cuba at different stages of tourism development have been chosen as the backdrop for the methodology: Cárdenas, an established tourism site and Caibarién, a new tourist development, both described below.

For this pilot project the main goal has been to gain broad knowledge about the relationships between globalization, tourism and impacts in the context of coastal communities. The outcome is a methodology for identifying how global forces affect social organization and wellbeing in communities, so that policy implications and options can be considered and comparative studies conducted to monitor vulnerabilities and the effectiveness of health-promoting policies. The main features of the methodology are community participation and rapid assessment of impacts for decision-makers.

It has been selected the combination of team meetings, lit- erature review, focus groups, key informant interviews, and review of secondary data (i.e. rapid assessment technique-rather than the conducting of household surveys or more extensive ethnographic study methods). The center piece of the methodology was a series of focus groups and key informant interviews to outline concerns, perceptions and observations related to tourism development.

The step-by-step methodology:

1) Meetings in Caibarién and Cárdenas

These meetings provided the venue for key informants' interviews, ensured cooperation by community leaders, engaged in further dialogue about the constructs, gained further background information about the community, and planed the details of the rapid assessment field work.

2) Definition of composition of focus groups (Appendix 1)

The research team planned four focus groups in each community ensuring a comprehensive coverage of the main stakeholders or people involved. These were decision-makers, community at large, health related workers and tourism related workers.

3) Preparation of the script for the focus groups (Appendix 2)

The script was used as a guide for the line of questioning of the focus groups facilitators.

4) Field research in Caibarién and Cárdenas

Focus groups were conducted with prior cooperation of key people in order to ensure participation. In each community the four focus groups were conducted simultaneously with duration of hour and a half each. The field work in the two communities was one month apart.

5) Transcription and revision of focus groups information

This step focused on determining the comprehensiveness of the information.

6) In-depth interviews

This step was used to complement information that might have been missed in the focus groups.

7) Analysis and summary of information

A matrix of impacts and dimensions (including mitigating policies/factors) for both communities was developed for a quick comparative analysis.

8) Feedback meeting

This is an important step that provides feedback to those who participated in any of the focus groups; at the same time it seeks additional information. It is particularly important that decision-makers are informed of the information gathered. This feedback meeting could adjust the results of the previous steps according to the opinion of the participants.

9) Identification of indicators

The qualitative information obtained to this point was matched to indicators that are routinely collected by the National Statistics Office. A form was developed to document details of the indicators such as source, availability, etc.

10) Data analysis

This final step allows for the establishment, verification and evaluation of the impacts of tourism on local communities.

\section{Results and Discussion}

\section{Context of the Study}

For the development of this study, two coastal communities have been selected, Cárdenas and Caibarién. Here are the most 


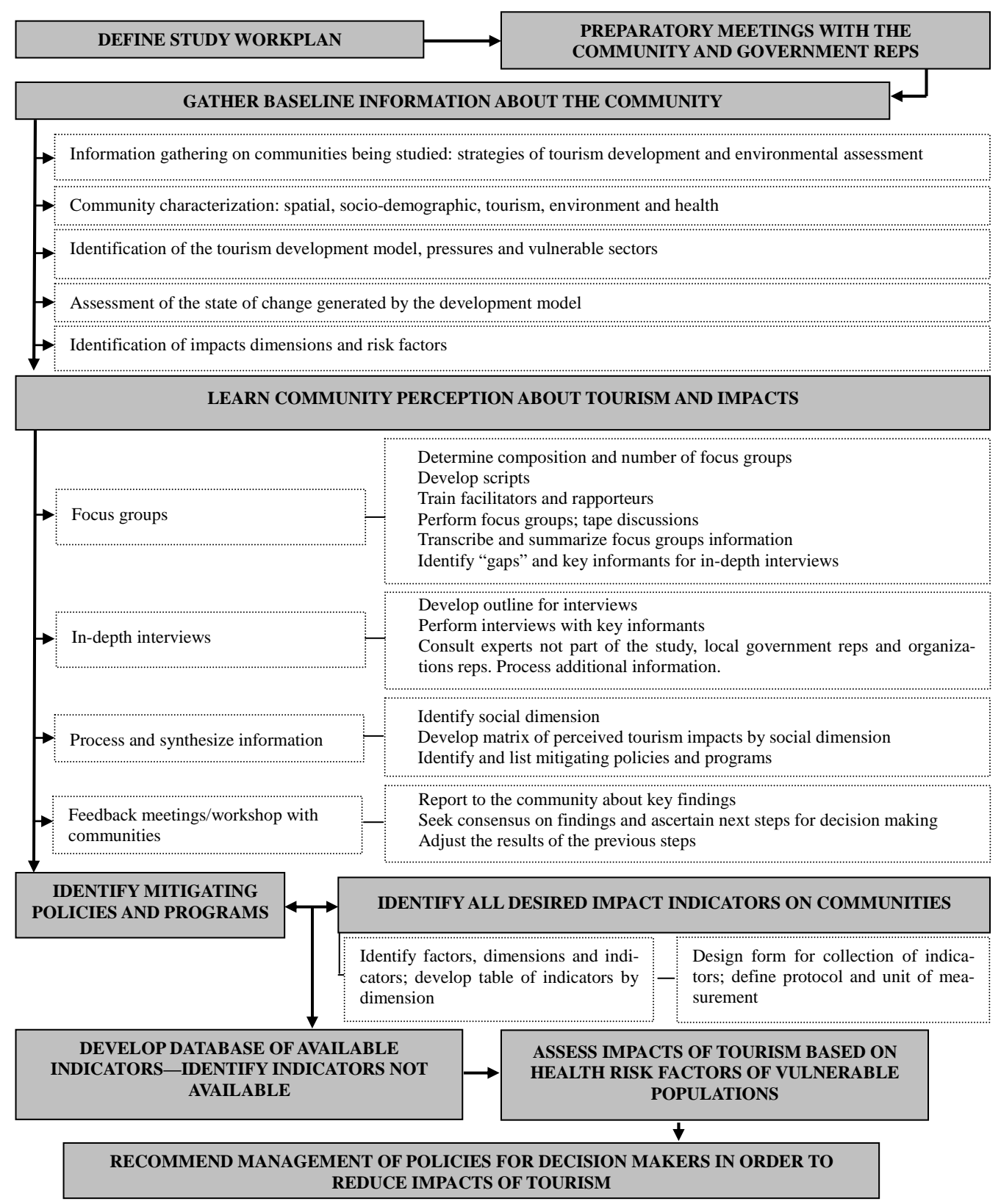

Figure 1.

Structure of the proposed methodological process for the analysis of impacts of tourism on coastal communities.

important characteristics identified.

\section{Cárdenas}

The municipality of Cárdenas has an area of $564.89 \mathrm{~km}^{2}$ which represents $14.8 \%$ of the Matanzas province, and $0.5 \%$ of the area of Cuba (Figure 2).

The area is defined to the north by the width of Florida and the municipality of Varadero. To the south, east and west, Cárdenas is bordered by Jovellanos, Limonar, Martí and Matanzas municipalities.

Cárdenas has a particularly advantageous geographical location because of its proximity to Varadero and Havana, the two most important locations for tourism in the country. This has significantly influenced the city's municipal development and on social and economic levels. Cárdenas has around 100,000 residents and a population density of 169 people per square kilometer. Eighty-one percent of the territory's population lives in the city itself.

The manufacturing, service and tourism industries constitute the fundamental economic activities that have been developed in the territory. The main extractive businesses in the area are the Drilling Company and the Petroleum Centre, which produce more than half of the total petroleum extraction in the country and about $70 \%$ of the natural gas production. The environmental condition in Cárdenas is marked by various environmental problems which may or may not be linked to tourism development in Varadero. According to the Municipal Environmental 
Strategy (CITMA, 2005), the municipality’s environmental problems are: contamination of ground and sea water, deterioration of sanitary hygiene conditions, lack of education, decreased environmental consciousness, deforestation, soil degradation, and loss of biodiversity.

\section{Caibarién}

The municipality of Caibarién has an area of $212.2 \mathrm{~km}^{2}$. It is located to the northeast of Villa Clara province, a location that has facilitated its economic and social development. It contains the coastal zone and an insular area where the small cays Las Brujas, Ensenachos and Santa María are known for their spectacular natural beauty. The cays have been attached to the mainland since 1994 by approximately $48 \mathrm{~km}$ of highway built above the sea. The highway, or Pedraplén, unites the insular zone, which was recently developed for tourism, with the coastal city of Caibarién (Figure 3).

Caibarién has a population of 40,798 , of which 20,118 are male and 20,690 are female. The population density is 148.89 people per square kilometer. Most of this population, 92 percent or 37,555 people, live in urban settlements. The population is predominantly adult and has a low growth rate and negative immigration rate. The structure of the local political administration is based on 7 popular councils, 3 of which are urban, 1 is suburban and 3 are rural.

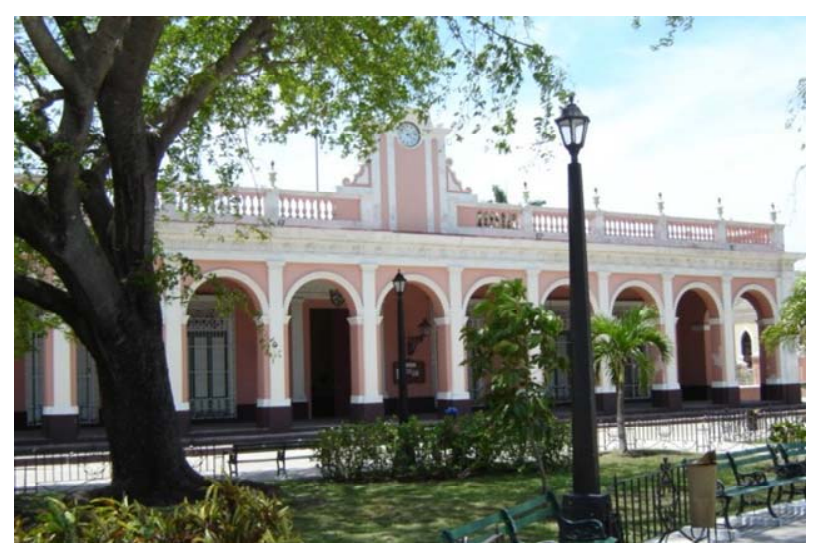

Figure 2.

Typical building in Cárdenas city, Matanzas.

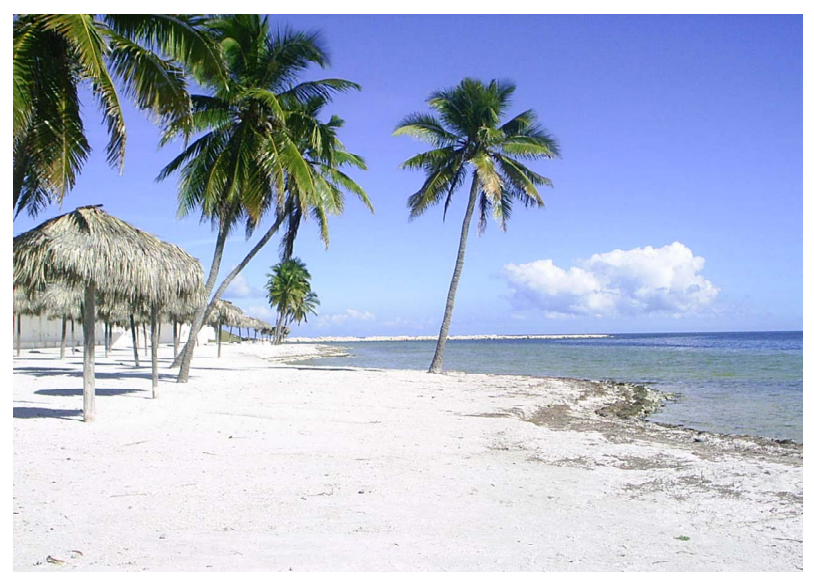

Figure 3.

Mar Azul beach, Caibarién, Villa Clara.
Caibarién has experienced important structural transformations in its traditional economy throughout history, which has been the cause of various social impacts. The port development failed in 1930 and the sugar industry ended in 2002 when the "Marcelo Salado" plant closed down under the new national development strategies. The plant was subsequently converted into the Agro-industry Museum while residents were forced to develop other economic activities. Nevertheless, the primary economic sector in the urban setting remained linked to the fishing and the service industries. Then, in the early 1990s, the city reopened to international tourism. Tourism proceeded to become an important local economic activity. It now takes place in the glorious beaches along the coastal cays, more than 50 km from Caibarién.

Caibarién's geographical location positions it as the primary source of labor for the tourism industry. Caibarién's cultural component complements the beach aspect of tourism in the region. It is expected that because of this additional attraction the interaction between tourists and hosts will increase. Caibarién is integrated as a tourist sub-region within the Villa Clara tourist area. It includes three beach resorts, Santa María Cay, Ensenachos Cay, and Las Brujas Cay, and one urban site (the city).

The resorts and the urban area complement each other and form a tourist attraction that has more than just the beach component. Currently, Caibarién does not have the capacity to lodge national and international tourists. The actual accommodation infrastructure consists of one hotel, five private hostels and rustic tourist villas, as well as some guesthouses. In comparison, the coastal cays offer an ample and very comfortable infrastructure with enormous potential for hotel development.

\section{Results of the Focus Groups}

Results obtained primarily from focus groups in Cárdenas and Caibarién, and also enriched by other sources according to the methodology, provide a broad view of perceived impacts of tourism (Figures $\mathbf{4}$ and 5).

\section{Economic Impacts}

Most participants in the focus groups recognized the importance of tourism for its national and local economy. The fol-

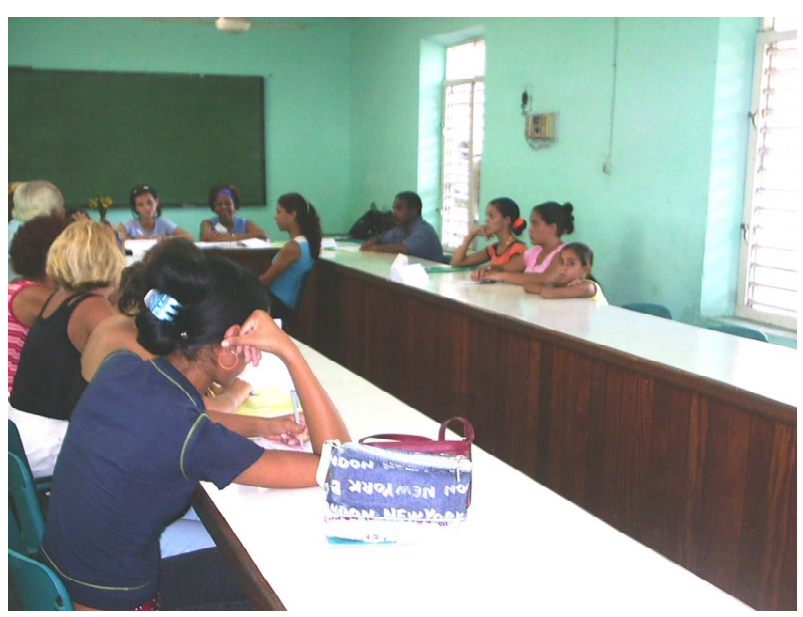

Figure 4.

Focal group in Cárdenas city, Matanzas. 


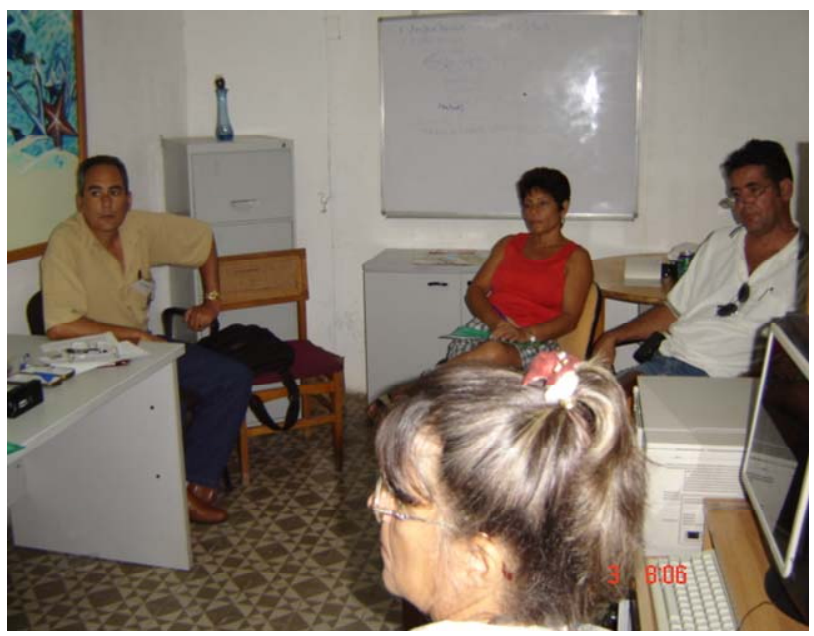

Figure 5.

Focal group in Caibarién city, Villa Clara.

lowing are some of the major issues that were identified from the discussions in the focus groups:

- Tourism has been used as an economic strategy in order to increase the overall economic level of the country. Tourism appears to have a multiplier effect.

- As a consequence, more jobs are created locally in different manufacturing and service sectors, especially for youth and women; less unemployment.

- Workers have higher wages and salaries.

- Higher family income, especially for those in the tourism industry.

- Tourism contributes to the development of social and economic programs in the country and the Municipality; the health and educational sectors have been sustained and even strengthened with the revenues from tourism.

- It represents the largest source of revenue for the country.

- More housing and better infrastructure in the community.

Although it was acknowledged that tourism contributes to the development of other economic sectors, a negative impact on the economy was identified as the disappearance of the fishing industry typical of coastal communities.

\section{Impacts on Labor}

- Work force is shifting from the health and education sectors to the tourism sector (Cárdenas)

- More job opportunities for youth

- Better working conditions in tourism sector

- Less protection by union regulations

- Competing work force coming from other areas

- Long work hours

- A lot of pressure from work (in tourism); important to keep the job to support the family

- Husband and wife may have different shifts

\section{Cultural Impacts}

Impacts on culture have been seen largely as positive if changing diet and fashion is not considered in this dimension. Comments about tourism can be grouped as follows:

- It provides the awareness to raise the cultural level of the community in areas such as languages, history and local and national traditions.

- It is a way of creating incentives to preserve and improve the cultural heritage as well as to promote the local culture and traditions.

\section{Educational Impacts}

- People achieve a higher educational and professional level through special courses that provide them with higher training in areas of tourism services.

- On the other hand, many university professionals seek jobs in the tourist sector, "even washing dishes", in order to make more money.

- Fewer students going to high school (Cárdenas).

\section{Social Impacts}

Social impacts of tourism on the community were perhaps the most widely discussed by participants in the focus groups.

Positive:

- Tourism contributes to a higher standard of living in general for the community.

- The community is more stable and permanent now in Caibarién; there is a beginning of a process of attraction of population from other areas to this Municipality

- Better housing - although mostly for tourism workers Negative:

- Increased prostitution-and increased STDs—as well as more drug consumption in Cárdenas; this is not perceived as a problem in Caibarién

- Increased corruption and illegal activities (Cárdenas)

- Deterioration of social values

- Increased immigration towards Cárdenas—some illegal

- Increased social disparity among Cubans-particularly negative for young people.

- Workers in the tourism sector earn more and have increased consumption and access to more goods; they also have preferential treatment as better and assured transportation.

- Barriers to get to tourist areas [this is also considered a mitigating factors that regulates the relationship between tourists and Cubans in hotels in order to prevent spread of STDs].

- Community lifestyle changes; someone said: "Everything changes.” Eating/diet habits, dressing fashion, friendships have broken.

- Exposure to other cultures produces a change in behavior and taste.

- Work in tourism is the main goal of youth.

\section{Impact on Women}

- It has generated more employment for women and more women work in the tourism sector; this has created problems where men used to be the main provider (Caibarién).

- Increased prostitution; some people entice the tourists to seek women (Cárdenas); no prostitution in Caibarién.

- Physical work is heavier for women.

\section{Impact on Family}

- Less time for the family; parents working in the tourism sector provide less care to their children.

- Husband and wife may have different shifts; this prevents 
them from spending time together (Cárdenas).

- Some families have split.

- More separations and divorces.

\section{Inter Sectorial and Social Cohesion}

- Lack of coordination between tourism sector and other sectors (decision-makers in Caibarién).

- No links between some municipal activities and tourism activities (decision-makers in Caibarién).

- All sectors of the community are involved (community group in Caibarién).

- Need to work with the police to ensure safety of tourists (Cárdenas).

- Stronger social cohesion: "there are no outcasts; they all look for the community well-being.” (Caibarién).

- Tourism worker has less contact with larger society.

\section{Political Impacts}

- As a driving force tourism has been recognized by decision makers and community members of Caibarién as a challenge to the ideology.

- "People need to be vigilant" particularly in relation to youth.

- Tourism is a way to show Cuban society and what we do.

\section{Environmental Impacts}

- Increased awareness about care of the environment; garbage is not dumped everywhere-some areas give a poor impression to tourists

- There is a larger volume of solid waste; as a result, Cárdenas has a new solid waste processing plant

\section{Health Impacts}

\section{Community}

- More garbage bins and garbage trucks; more frequent garbage collection; more control of vectors

- Broader view of health that includes a healthy environment

- "People are more aware about health."

- Better sanitation but water supply still a problem (Cárdenas)

- Workers in tourism have vaccine shots and other tests as prevention

- Tourism workers have some more privileges than health workers

- Fear of importing exotic diseases already eradicated in Cuba (cholera, vector-borne)

Physical

- Higher prevalence of hypertension, pelvic problems and exposure to disinfectants and cleaners among tourism workers

- Obesity, cerebral-vascular diseases, heart attacks, arthritis, high cholesterol level

- Physical work is heavier for women-long hours standing: more propensity to back problems, pelvic problems and varicose veins

- Danger of sexually transmitted diseases (STD); 60\% of HIV + cases are related to tourism

- More concern about keeping in shape, getting massages, green medicine, better diet, reduction in smoking
Psychosocial

- “Tourism has a psychological impact on people."

- "Psychological impact is manifest in the difficulty to satisfy material needs for those who do not work in the tourist sector."

- Work related stress

- Alcoholism

- Drug use; addictions (Cárdenas—no problem in Caibarién)

- Some families have become dysfunctional

\section{Mitigating Policies}

A series of policies or strategies have been mentioned by all focus groups that have been implemented in order to mitigate the negative impacts of tourism on the community. Some by area of concern are:

\section{Health}

- Community committees with a large representation have been developed for the prevention and control of HIV and STDs; extensive use of media

- Continued diagnostic about drug use and addiction

- Early warning system to detect exotic diseases

- Epidemiological surveillance for vectors

- A program to discuss environmental health: "My nice home \& my healthy home" (Caibarién)

- Strategies at the municipal level for the protection of the environment and the coast specifically

- Regulation of the relationship between tourists and Cubans in hotels in order to prevent spread of STDs

- Deployment of physicians in all tourist hotels

- Deployment of social workers for general problems (Caibarién)

\section{Community}

- Policy to control illegal immigration into the municipality of Cárdenas

- Vocational orientation for children and youth to guide them to enter professions that are needed in the country

- University involvement in development and research projects for the municipality

- Weekly "System meetings" with health professionals community and political leader (Caibarién)

- Continued effort in ideological work from the grass roots level to stop the impact of tourism on youth and the community; neighborhood meetings called "Barrio debate" (Neighborhood debates) (Caibarién)

- Community programs: "Jardines del Rey”, "Adolescencia Feliz” and others for seniors and housing (Caibarién)

- Workshops with workers to discuss job and social concerns (Caibarién)

\section{Discussion of the Results}

This pilot study proposes a practical methodology for a rapid community-based assessment of the impact of tourism on coastal communities. Focus groups appear to be an accurate initial gauge of the process of tourism development and the broad coverage of the focus groups to include all community stakeholders is a key element.

Overall, the interventions of participants were active and in- 
formed and addressed the areas of interest. A preliminary analysis of the information appears to imply issues related to globalization as a driving force for tourism development and its impacts. The assumption that globalization brings pressure to adopting a certain ideology, seems to have been identified in the statement "tourism brings changes to the ideology."

Other issues linked to globalization were:

- Tourism is good for the economy, but it appears to have disruptive impacts as displacing traditional sectors (fishery) and displacing people and work force.

- Socially it has created disparities.

- On the positive side, local culture can be projected to other countries; but this puts pressure on the local community to develop a cultural and social infrastructure that presents the best.

- Tourism brings changing lifestyles: “everything changes”. The link between tourism and local communities has been highlighted in terms of impacts on physical and mental health. The impact of tourism on gender is very evident for the local communities. While there are more jobs available to women, the emphasis on the increased prostitution shows a strong negative impact on women. A comment was made about affecting the family dynamics with changing roles as "main provider" in the family. Other impacts on the family will likely affect women as well.

The focus groups discussions in Cárdenas and Caibarién also reflect the different stages of tourism development in the two communities. In general, Caibarién seems to be better prepared for the impacts of tourism as indicated by the more specific programs and policies aimed at mitigating the negative impacts. Early results of this preparedness may be inferred by the statement "In Caibarién it is not like in other municipalities... like Varadero [Cárdenas] [and] Havana where there have been more tourists and more negative impacts.” In fact, prostitution and drug addiction have not been identified as current problems as in Cárdenas. There is a similar relation between the shift in the work force toward tourism and uncontrolled immigration in the community.

Caibarién might be in the early stage of "relationship" with tourists as suggested by statements such as "tourists learn more about Cuba while interacting with Cubans", and "it allows us to promote our culture in the world." A full verification of the methodology may only occur with an analysis of the indicators or measures of the suggested impacts. Nevertheless, the methodology proposed in this pilot study appears to validate some of the assumptions about the pathways between globalization, tourism and impacts. Negative impacts are inevitable and only early proactive policies may provide the prevention of those impacts.

These negative impacts are inevitable because they have already been felt by the local community, who has perceived them in this way. Therefore, it is necessary to reconsider the preventive management of impacts related to policies and control strategies needed to eliminate, mitigate, compensate, and develop resistance/adaptation capacities, as well as monitor and create surveillance systems on the effects perceived by the community (Figure 6).

\section{Conclusion}

According to the opinions and behaviors of the participants in the focus groups developed in Cárdenas and Caibarién it is

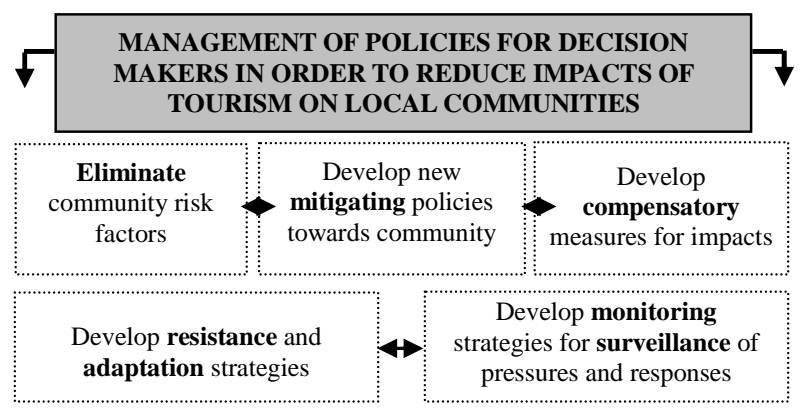

Figure 6.

Possible preventive measures of negative impacts perceived by the community.

recognized that the expansion of tourism on coastal communities directly and/or indirectly affects them. It is an important point to project alternatives for development based on the perception of the tourism model implemented at the local destination, allowing the possibility to improve the relationship between tourism and the host community.

The pilot study concluded that the local community is able to identify the links between tourism development and its impacts. They can explain pathways that link the impact of tourism, and the policies that influence them. Also, direct and indirect effects on the local communities across their lifespan are perceived, with emphasis on the evolution of impacts on social organization.

Field research conducted in Cuba also demonstrates that tourism impacts vary at different stages of tourism development. The know-how developed in Cárdenas regarding the traditional model of tourism could be an appropriate way of promoting an alternative model of tourism development based on sustainable principles. Due to the different stages of development both cities are in, it is perfect timing to promote a preventive plan for controlling negative impacts of tourism perceived by the community in Caibarién.

Comprehensive qualitative and quantitative indicators were identified by the focus groups in Cárdenas and Caibarién. These might be indicative of the "real" impact of tourism and could be used to develop future research projects. Both men and women felt adequately represented by the indicators, and showed consensus on indicators and research/measurement protocols based on their own experiences.

Mitigating policy measures to protect and promote tourism development were recognized by the local community. It is possible to develop preliminary consensus on the policy implications and policy options among policy-makers, researchers and community leaders. They are able to identify a series of strategies and actions in order to mitigate the negative impacts of tourism on the community according to different areas of concern.

As a research learning experience this study provides a methodology to identify how tourism affects social organization in communities, in order to consider different policy implications and management options. At the same time it offers empirical evidences based on a case study for those interested in rapid assessment of tourism impacts through community participation.

The value of the results is related to the projection of new strategies of management for the future development of tourism in both communities; Cárdenas which is located near a mature 
destination like Varadero, and Caibarién which associated with the new destination of Cayos de Villa Clara. The next stage could be a proposal of a preventive plan for impacts management; it should be designed according to the community perceptions of the impacts of tourism, and the policies that influence them.

The findings could be applied to a wider global community in Cuba. It is recommended to improve the methodological approach developed with the participation of the community applying a Rapid Assessment Technique. This brings together the local communities' residents with policy-makers, researchers and community leaders; generating space for understanding, learning, and engagement of all social and economics agents.

\section{Acknowledgements}

The authors thank research study team members: J. Spiegel, N. Pagliccia, G. J. Cabrera, S. Catasús; and O. Diaz.

\section{REFERENCES}

Arcarons, R., \& Datzira, J. (2005). Los destinos turísticos locales. Singularidad en la gestión. Material Didáctico, Máster en Gestión de Destinos Turísticos Locales, España: CETT. Universidad de Barcelona.

Ayala Castro, H. (2001). Medio Siglo de Transformaciones del Turismo en Cuba. Gestión Hotelera y Turismo. Facultad de Contabilidad y Finanzas. Universidad de La Habana.

Busch, M., Arnal, E., \& Frances, G. (2005). Estrategias para el Desarrollo Sostenible de los Destinos Turísticos Locales. Material Didáctico. Máster en Gestión de Destinos Turísticos Locales, España: CETT. Universidad de Barcelona.

Cabrera, J. G. (2004). Saber ambiental y desarrollo turístico sostenible. Master Internacional de Turismo de la Universidad de Las Palmas de Gran Canarias, España.

Cohen, E. (1984). The sociology of tourism: Approaches, issues and findings. Annual Review of Anthropology, 10, 373-392.

Cooper, C., \& Michael, H. C. (2007). Contemporary tourism. London: Routledge, Taylor \& Francis Group Ltd.

Edgell, D. L., \& Jason, S. (2013). Tourism policy and planning yesterday, today, and tomorrow (2nd ed.). London: Routledge, Taylor \& Francis Group Ltd.

Fernández, T. A. (2002). La gestión local del desarrollo turístico: Competitividad, sostenibilidad y participación social. En Turismo y Sostenibilidad. Un acercamiento multidisciplinario por el análisis del movimiento y de las estrategias de planificación territorial. Brigati Genova, 111-122.

Francesc Valls, J. (2004). Gestión de destinos turísticos sostenibles. Gestión 2000, España.

Freitag, T. (1996). Tourism and the transformation of a Dominican coastal community. Urban Anthropology, 25, 225-257.

González, H., \& Manuel, R. (2006). Gestión Ambiental de los Impactos del Turismo en Espacios Geográficos Sensibles. Editorial Abya-Yala. Quito, Ecuador.

González, H., \& Manuel, R. (2010). Gestión Ambiental en el Turismo y la Hostelería. Editorial CEP S.L. Madrid, España.

González, H., \& Manuel, R. (2012). Cultura Turística de la Población Local Anfitriona del Turismo. Editorial Académica Española.

Gössling, S., Michael, H. C., \& David, W. (2012). Sustainable tourism futures. Perspectives on systems, restructuring and innovations. London: Routledge, Taylor \& Francis Group Ltd.

Guevara, A. A., \& Marcus, V. C. (2009). Turismo Sustentable. El equilibrio necesario en el siglo XXI. Editorial Trillas, S.A. de C.V. México.

Hall, C. M., \& Alan, A. L. (2009). Understanding and managing tourism impacts. An integrated approach. London: Routledge, Taylor \& Francis Group Ltd.
Hall, D., \& Greg, R. (2003). Tourism and sustainable community development. London: Routledge, Taylor \& Francis Group Ltd.

Harris, P. (2011). Profit planning for hospitality and tourism (3rd ed.). Oxford: Goodfellow Publishers Ltd.

Huynen, M. P., \& Hilderink, H. (2005). The health impacts of globalisation: A conceptual framework. Globalization and Health, 1, 14. doi:10.1186/1744-8603-1-14

Instituto Nacional de Investigaciones Económicas (INIE) (2005). Efectos y Futuro del Turismo en la Economía Cubana. Uruguay: Impreso en TRADINO S.A.

Ivarsi, B., Josep, A., Isabel, R. S., \& José, F. V. R. (2013). The evolution of mass tourism destinations: New approaches beyond deterministic models in Benidorm (Spain). Tourism Management, 34, 184 195. www.elsevier.com/locate/tourman

Joseph, C., \& Kavoori, A. (2001). Mediated resistance: Tourism and the host community. Annals of Tourism Research, 28, 998-1009. doi:10.1016/S0160-7383(01)00005-6

Kila Reimer, J. K., \& Pierre, W. (2013). How do you know it when you see it? Community-based ecotourism in the Cardamom Mountains of southwestern Cambodia. Tourism Management, 34, 122-132. www.elsevier.com/locate/tourman

Labonte, R., \& Torgerson, R. (2002). Frameworks for analyzing the links between globalization and health. Draft report to the World Health Organization. Saskatoon: SPHERU, University of Saskatchewan.

Lankford, Samuel, V., Jill, L., Oksana, G., \& Richard, H. (2013). Introduction to tourism a community-based approach. Sagamore Publishing LLC.

Legrand, W., Claudia, S.-K., \& Philip, S. (2012). Sustainable hospitality and tourism as motors for development. Case studies from developing regions of the world. London: Routledge, Taylor \& Francis Group Ltd.

Leigh, J., Craig, W., \& Stanislav, I. (2012). Future tourism. political, social and economic challenges. London: Routledge, Taylor \& Francis Group Ltd.

Mason, P. (2008). Tourism impacts, planning and management (2nd ed.). London: Routledge, Taylor \& Francis Group Ltd.

Ministerio de Ciencia, Tecnología y Medio Ambiente (CITMA) (2005). Estrategia ambiental municipal 2005-2010, Cárdenas, Matanzas, Cuba.

Organización Mundial de Turismo (2005). Indicadores de desarrollo sostenible para los destinos turísticos: guía práctica. Madrid: Publicado por la OMT.

Osácar, E., López., E., \& Vilaginés, A. (2005). Instrumento de Gestión Estratégica del Turismo. Material Didáctico. Máster en Gestión de Destinos Turísticos Locales. CETT. España: Universidad de Barcelona,

Spiegel, J. M., \& Andruske, C. L. (2005). Globalization, health and the engendering of resistance in everyday life. In I. Kickbusch, K. Hartwig, \& J. List (Eds.), Globalization, women and health in the 21st Century. Hampshire: Palgrave Macmillan.

Spiegel, J. M., Gonzalez, M., Cabrera, G. J., Diaz, O., Vidal, C., \& Catasus, S. (2006). Responding to globalization's impacts on health: Adapting a conceptual framework to prepare for global tourism expansion in Cuba.

Spiegel, J. M., Labonte, R., \& Ostry, A. (2004). Understanding “globalization” as a determinant of health determinants: A critical perspective. International Journal of Occupational and Environmental Health, 10, 360-367.

Stonich, S. (2000). The other side of paradise: Tourism, conservation, and development in The Bay Islands. New York: Cognizant Communication Corporation.

Taylor, F. (1993). To hell with paradise: A history of the Jamaican tourist industry. Pittsburgh: University of Pittsburgh Press.

Tsung Hung, L. (2013). Influence analysis of community resident support for sustainable tourism Development. Tourism Management, 34, 37-46. www.elsevier.com/locate/tourman.

Wonders, N. A., \& Michalowski, R. (2001). Bodies, borders, and sex tourism in a globalized world: A tale of two cities-Amsterdam and Havana. Social Problems, 48, 545-571.

doi:10.1525/sp.2001.48.4.545 
Appendix 1. Focus groups.

\begin{tabular}{cccc}
\hline 1-Decision makers & 2-Community & 3-Health & 4-Tourism \\
\hline Know and manage the social system & $\begin{array}{c}\text { Experience the system as } \\
\text { participating social beings } \\
\text { Tourism }\end{array}$ & Know the health care system & Know the tourism sector from the inside \\
Agricultural sector & Federation of Cuban women & Nurse in tourism setting & Tourist resort \\
Commerce and services & Popular council & Psychologist & Travel agency \\
Community services & Social worker & Epidemiologist & Transportation \\
Industry & Teacher & CITMA ${ }^{2}$ & Tourist information office \\
Housing & Cultural promoter & Community services & Female worker in tourism \\
Municipal statistical office & Family doctor (not in tourism) & Environmental educator & Food preparation rep \\
Police & Nurse (not in tourism) & & Hotel Reception \\
City planning & Association of small farmers rep & & Kitchen worker \\
Communist Party of Cuba & Workers rep & Entertainment \\
Local government rep & & & Waitress
\end{tabular}

Note: ${ }^{1}$ Committee for the Defense of the Revolution; ${ }^{2}$ Ministry of Environment.

\section{Appendix 2. Guidelines for Focus Groups}

\section{General Instructions}

The focus groups will be recorded. Nevertheless, the facilitators should take written notes in order to identify the speaker (not the name, just whether the person speaking is, for example, the cultural promoter or the social worker, etc.). Even though the information will be processed electronically, it is also necessary for the focus group facilitators to record personal notes on their perceptions of the interventions. This will help in the mechanical processing later. If possible, the focus groups should have a good representation of women and men, age, occupation, etc.

\section{Focus Group \#1-Decision Makers}

Participants: Actors and experts from the social system.

Objective: This group is made up of individuals who hold leadership positions and make decisions in various areas and levels in Caibarién and Cárdenas. We would like to gain perspectives on tourism and the impacts it may have in all of the areas of interest to the participants. In particular, we must share specific details on the measurable effects of the negative impacts.

\section{Questions:}

1) What importance does tourism have for:

- Cuba

- The Province

- Society

- Caibarién/Cárdenas

Instructions: The discussion should reflect what the participants express about tourism as well as how this important subject transpires. What outcomes or benefits does tourism bring and in what areas of society do they occur (economy, culture, health, environment, etc.)?

2) What impact (desirable or undesirable) does tourism have on the following human and social aspects: The Environment, Physical and Mental Health, The Community/City (Caibarién/ Cárdenas), Urban Services, Housing, Education, Crime, Workers, Women, Children, Elderly, Family, Social Values, Culture, Food Production.

Instructions. Direct the discussion so that participants explain in detail the desirable and undesirable impacts of tourism in each area. It is important to elicit whether or not a causal relation exists between tourism and the listed aspects. For example, it can be said that the amount of trash in the streets has increased as a result of tourism (undesirable impact); it can also be said that that have been major efforts to maintain clean streets in order to enhance tourism (desirable impact); it can also be said that the streets have always been clean (there is no relation to tourism).

3) As decision makers, what do you perceive are the most desirable impacts that result from tourism and what do you perceive are the less desirable impacts that would require a solution or compensatory action?

Instructions. This question should focus on some of the impacts, ordered by degree of importance, perceived by the decision makers.

4) As decision makers, what are some of the most important measures that have been taken during the past year, in your capacity, to prevent or mitigate undesirable impacts of tourism?

Instructions. Obtain details that indicate policies or compensatory actions that the decision makers have taken to counteract undesirable impacts or to create desirable impacts.

\section{Focus Group \#2—Community}

Participants: Those that experience the system as members 
of society. Make sure that there is equal representation from men and women, those single and married, and from various occupations in order to capture diverse perspectives.

Objective: The group will be made up of participants that DO NOT work in tourism and represent a cross section of the community. They experience the impacts of tourism in many areas including (and especially) health. This impact is as much physical as mental, and impact areas on a socio-environmental level and in the community without necessarily benefiting directly from tourism. The objective is to obtain participants' perspectives on tourism and its impacts both on a personal level and on the community of Caibarién/Cárdenas.

Questions:

1) What importance does tourism have on:

- Cuba

- The Province

- Society

- Caibarién/Cárdenas

Instructions. The discussion should obtain participants' reflections on the relevance of tourism at different levels from the general level to more specific impacts on a personal level.

2) What is your opinion on how your community is developping tourism and what do you perceive are the changes that have occurred because of tourism?

Instructions. Facilitate a discussion about how changes have been perceived regarding the environment, changes socially and culturally, changes to physical and mental health, changes in negative behaviors (like alcohol use, etc.) and positive changes (like housing improvements, etc.). Try to cover the majority of human and social aspects.

3) What specific actions have been taken to counteract the changes that you have perceived as negative?

Instructions. Obtain details from actions that individuals have taken in their communities against the undesirable impacts on environmental, social, cultural, physical and mental health levels.

\section{Focus Group \#3-Health}

Participants: Those familiar with health from the perspective of tourism workers.

Objective: This group is comprised of individuals who through their work have a good understanding of health issues. The participants work in tourism or are very familiar with tourism. We want to establish a description of health in the broadest sense through the eyes of those in the tourism sector. There are four areas of focus: physical health, mental health, stress, and protective/compensatory factors.

Questions:

1) What is your perception of the changes to physical health that you attribute to tourism in people who work in tourism and those who do not?

Instructions. Focus on respiratory and sexually transmitted diseases, obesity, etc. (have the list of health indicators ready).

2) What is your perception of the changes to mental health that you attribute to tourism in people who work in tourism and those who do not?

Instructions. Focus on the occurrence of depression, anxiety, alcoholism, sleeping disorders and other mental health factors that emerge from the group discussion.

3) What is your perception of the changes to stress occurrence/levels that you attribute to tourism in people who work in tourism and those who do not?

Instructions. Facilitate a discussion of work-related stress, interpersonal (couples and family) stress, economic stress, and stress around providing education for children.

4) What is your perception of individual or community actions taken to mitigate or prevent the occurrence of stress or mental health disorders in people who work or do not work in tourism?

Instructions. Facilitate a discussion around personal strategies to lessen the effects of stress, for example, taking personal time for the children or partner, practicing religion, or listening to music. For the community level, discuss how community organizations and the community as a whole, as well as cultural activities, etc., help to alleviate stress.

\section{Focus Group \#4-Tourism}

Participants: Those familiar with tourism through direct experience. Make sure men and women are equally represented, as well as single and married individuals and racial groups, in order to capture a diversity of perspectives.

Objective: The group is comprised of people who work in tourism (from managers to cleaning staff) or who are directly linked to the sector and who experience direct impacts. The participants experience the effects of tourism on health and its links to the environment.

Questions:

1) What importance does tourism have on:

- Cuba

- The Province

- Society

- Caibarién/Cárdenas

Instructions. The discussion should obtain participants' reflections on the relevance of tourism on different levels from general to personal.

2) What experiences have been significant for you in the tourism industry?

Instructions.

a) In the following areas, try to cover your experiences with working in tourism:

- Labor-Relations between workers, differences between various areas of tourism work, what it means to have to switch to another area of work, why some fishermen now work in the service industry or technical work instead of as fishermen.

- Relationships with family, partner, and friends-Discuss whether there have been changes in the time and quality of relationships with spouses, children, parents, friends, etc.

- Children's Education-Facilitate the sharing of personal anecdotes about how children are affected by working parents. How? Positive; negative; how, for example, has behavior changed, and why?

- Economic Impact-Discuss whether the participants feel more economic responsibility within the family, if there is stress around losing work, maintaining or getting work at a hotel or in other tourism-related work.

- Emotional-Discuss on a personal level the emotional impact of tourism. How does it feel to work in tourism? For example, happy, at ease, hopeful, discontented, demoralized, deceived, indifferent, etc.

- Social and Cultural-Discuss whether they have experienced changes in the way they relate to or behave in their 
- community. Include a cultural dimension, in other words, whether they have noticed changes in cultural activities, whether they continue to attend cultural activities or not, whether they participate/organize cultural events or not, how often do they attend, and what importance does cultural participation have in their lives?
3) What specific actions have been taken to counteract those experiences that you perceive as negative?

Instructions. Obtain details of the actions that individuals have taken on their own initiative to counteract the undesirable impacts on the aforementioned aspects of tourism. 